\title{
A Test of Audit Pricing in the Small-Client Segment: A Comment
}

\author{
WILLIE E. GIST*
}

\begin{abstract}
This study is the second to provide a richer test of the association between auditor size and audit fees by using three audit firm size classes in the small-client segment of the U.S. audit market. The finding of a Big 8 (now Big 6) price premium is consistent with Francis and Simon [1]. However, this price premium exists only with respect to local/regional firms. Francis and Simon showed that the Big 8 price premium exists with respect to both second-tier and local/regional firms. The present study also provides evidence of a second-tier price premium over local/regional firms. The results imply product differentiation to both Big 8 and second-tier firms. Plausible reasons for differences in results between the two studies are given.
\end{abstract}

A study by Francis and Simon [1] of audit pricing in the small-client segment of the U.S. audit market provides evidence consistent with the finding of Palmrose [2] that a Big 8 (now Big 6) ${ }^{1}$ price premium is observed for small auditees. The study by Francis and Simon [1] was undertaken since Simunic [3] and Palmrose [2] reported contradictory findings about a Big 8 audit price premium in the "small" auditee segment of the U.S. audit market for publicly traded companies. Simunic [3] found no price difference between Big 8 and non-Big 8 auditors for small auditees. Francis and Simon [1] concluded that size sensitivity in the U.S. audit market might explain the different results obtained by Palmrose [2] as compared with Simunic [3]. Auditee size is comparable between studies by Francis and Simon and Palmrose (mean assets of $\$ 30-40$ million) compared with somewhat larger firms in Simunic's (mean assets of $\$ 177$ million) study. ${ }^{2}$

In addition to providing evidence on audit pricing in the small-client segment

*Assistant Professor of Accounting, School of Accounting, University of Oklahoma

1. The Big 8 auditors were Arthur Andersen, Arthur Young, Coopers and Lybrand, Deloitte Haskins and Sells, Ernst and Whinney, Peat Marwick Mitchell, Price Waterhouse, and Touche Ross. Since the collection of data for this study in 1987, Ernst and Whinney and Arthur Young merged; and, Deloitte Haskins and Sells and Touche Ross merged. These firms arc currently referred to as the Big 6 instead of the Big 8.

2. Francis and Stokes [4] demonstrate that the ability to observe a Big 8 price premium may be sensitive to the definition of auditee size. They observed Big 8 premiums for very small auditees (mean assets of $\$ 1.8$ million Australian) as did Francis [5] for somewhat larger auditees (mean assets of $\$ 49$ million Australian), but Francis and Stokes did not observe a Big 8 price premium for the very largest auditees (mean assets of $\$ 603$ million Australian). 
of the U.S. market, Francis and Simon is the only study to date to use three classes of audit firm size in addition to the Big $8 /$ non-Big 8 dichotomy. The classes were Big 8 firms, second-tier firms, ${ }^{3}$ and other local or regional firms. The use of three size classes provided a richer test of the association between auditor size and audit fees than in prior audit fee research. They found that the Big 8 price premium exists with respect to both second-tier national firms and local/regional firms. Since the assumption of competitiveness in the small auditee segment (due to the large number of audit suppliers) can be made a priori, the cxistence of a price premium implies Big 8 product differentiation.

The purpose of the present study is to provide additional tests of pricing by second-tier firms compared to Big 8 and to local/regional firms. The need for this research is evident by the fact that few studies have focused on the small-client segment of the U.S. audit market, and Francis and Simon is the only study to provide evidence on pricing by second-tier firms. This study covers the same time period as Francis and Simon and also uses the three classes of audit firm size in addition to the Big 8/non-Big 8 dichotomy. Since Francis and Simon is the only study to use three firm size classes, its replication would provide confirming cvidence; if the results are not replicable, that will also be of intercst. The basic pricing model developed by Simunic [3], and subsequently used in other audit pricing studies, is used for the present study.

\section{Sample Selection and Research Design}

A sample of 287 publicly held companies with assets of less than $\$ 150$ million was contacted during 1987 through a questionnaire mailed to the controller or chief financial officer. The criteria for the selection of companies (auditees) was as follows:

1. The auditee must be a publicly held company listed on the New York Stock Exchange (NYSE), the American Stock Exchange (AMEX), or Over the Counter (OTC).

2. The auditee must not be a foreign based company or a subsidiary of another company.

3. The auditee must not be a conglomerate.

The sample consisted only of publicly held companies. Criterion 2 was included to make sure the fee was not counted more than once, and criterion 3 was included to

3. The second-tier firms are Alexander Grant, Fox \& Co., KMG Main Hurdman, Kenneth Leventhal, Laventhol and Horwath, McGladrey Hendrickson and Pullen, Oppenheim Appel Dixon, Pannell Kerr Forster, and Seidman and Seidman. These firms have been identificd as making up the secondtier by such sources as the Public Accounting Report and The Accounting Wars [13]. Alexander Grant and Fox \& Co. merged in 1985; however, there are no audits in the sample, of the present study, done by the merged firm. Peat Marwick Mitchell merged with KMG Main Hurdiman in 1986. These mergers were taken into consideration when defining the sample period, of the present study, as 1983-1985 to avoid confounding effects of the merged firms. 
avoid confounding effects of auditees operating across regulated and nonregulated industries precluding identification of the major industry in which the auditee operates. The sample size was determined, in part, based on industry membership and expected response rate. For instance, companies identified in certain industries (e.g., air transportation, railroad transportation, beverages, and motor vehicle and equipment) were dropped from the sample due to a perceived lack of interest to participate and an informal assessment of the cost-benefit of sampling these companies. To ensure that second-tier and other local/regional auditors wcre included, the sample was further restricted to auditees with assets less than $\$ 150$ million. This same size cutoff was used to define small auditees by Palmrose [2], and is comparable to the size cutoff of $\$ 125$ million in sales used by Francis and Simon [1]. The sample size was limited further by excluding initial audit engagements because of the possible effects of price cutting or low balling and by budgctary constraints.

Standard and Poor's Register of Corporations, Directors, and Executives [6] and Who Audits America [7] were used as the data sources. The one page questionnaire consisted of items on audit fees, consolidated subsidiaries, number of physical operating locations visited by the cxternal auditor, and internal audit activity, which were not available from public data sources such as the annual report and Who Audits America [7].

Data for fiscal years ending 1983 through 1985 were requested on each auditee. ${ }^{4}$ Sixty-three companies responded for a 22 percent response rate. ${ }^{5}$ Observations for eight companies in the sample were not usable because the audit fee was not separable from other fees paid to the external auditor, and/or there were incomplete data items. The usable sample of 55 companies represents 19 percent of the original sample of 287 companies, or 87 percent of the 63 responding to the survey. One hundred thirty-nine responses were obtained from the 55 companies retained in the sample. Some companies indicated that the data was not readily available for earlier years.

Based on the literature $[1,2,3,4,5]$ referred to previously, the following set of variables is selected to control for cross-sectional differences in external audit fees: auditee size (Assets), number of consolidated subsidiaries (Subs), foreign assets (FA), return on investment (ROI), long-term debt to total assets (DA), internal audit activity (IAA, measured as annual internal audit payroll to total assets), type of

4. Three years of data were requested to assess whether any systematic differences existed among the sampling years. When dummy trend variables were included in the model to identify the year of the audit fee observation, they were not found to be significant. The trend variables did not indicate a systematic difference among sampling years and these variables, therefore, are omitted from the models. The Durbin-Watson (DW) statistic was examined because of the possibility of serial dependency from using three years of pooled data. The DW statistic of 1.602 and the first-order autocorrelation coefficient of .132 indicate no evidence of serial correlation. The results of these tests provide the basis for pooling the observations across the sample years.

5. This study covers fiscal years ending in 1983-1985, whereas Francis and Simon's study covers fiscal years ending from January 1, 1984, through June 30,1985 . The response rate (22 percent) of this study is also comparable to that (23 percent) of Francis and Simon. 
audit opinion (OP), and an indicator of regulated/nonregulated industry membership (I).

Control variables measuring total year-end assets (Assets), the number of consolidated subsidiaries (Subs), and foreign assets to total assets (FA) are intended to control for the size and complexity of auditee operations. Simunic [3] defined thesc factors as "loss exposure" variables or the amount of assets the auditee has at risk.

Control variables measuring the type of audit opinion (OP), net income or loss to total assets (ROI), and total long-term debt to total assets (DA) are intended to control for the loss-sharing ratio between the auditor and the auditee since each can be held jointly and severally liable for misleading financial statements. These variables are constructs of factors that measure the amount of financial distress of the auditee. It is expected that the lower the return on investment, the higher the audit fee; and, the higher the amount of long-term debt in the capital structure, the higher the audit fee. In these situations, the greater financial distress of the auditee results in greater risk being assumed by the auditor. Also, qualified "subject to" opinions (OP coded " 1 ") are expected to result in higher audit fees than unqualified and consistency exception opinions (OP coded ' $O$ "). The uncertainty associated with the "subject to" qualified opinion results in greater risk and/or additional audit procedures for the auditor.

Internal audit activity (IAA) and industry membership (I) were not included in the model by Francis and Simon [1]. The variable (IAA) measuring internal audit activity is a surrogate for the amount of work performed by the internal audit department. Studies by Palmrose [2] and Wallace [8] indicatc a ncgativc relationship between the amount of audit fees paid and the amount of work performed by the internal audit department. Thus, the inclusion of this variable would appear to be necessary for a properly specified model.

Studies by Palmrose [2] and Simunic [3] indicate that audit fees tend to be higher in nonregulated industries compared to regulated industries. Since the theory for this finding is not well developed, no direction is hypothesized for the industry variable (I) of the present study. Danos and Eichenseher $[9,10,11]$, however, provide evidence that client regulatory complexity confers scale opportunities to large CPA firms. They posit that these production economies of scale exist, in general, in the context of specialization. If cost savings are passed on to the auditees, the work of Danos and Eichenseher would seem to suggest higher fees charged by large CPA firms in nonregulated industries compared with regulated industries. This would also seem to support the findings of Palmrose and Simunic. On the other hand, higher fees charged in regulated industries should not be a surprise. To the extent that regulation demands greater auditor expertise, one would expect that auditors would price in order to recover their investment incurred in generating that expertise. Thus, the economic rationale would support the prediction of a higher fee.

Once these variables are controlled, an audit firm size test variable is added to the model. A Big $8 /$ non-Big 8 firm size variable is added to the model for the 
total sample. Subsequently, three subsamples are created, testing the following dichotomous firm size variables: Big 8 versus second-tier firms, Big 8 versus other local/regional firms, and second-tier versus other local/regional firms. A fifth model tests both Big 8 and second-tier firm size indicator variables for the total sample. Again, Francis and Simon is the only study to date to provide evidence on this richer test of the association between auditor size and audit fees. A replication of their findings would be a contribution to the literature; on the other hand, if their results are not replicable, this would also be a contribution and would indicate a need for further research in the area.

The final fee model selected is as follows:

$$
\text { Lfee }=\text { SQAssets + SQSubs + FA - ROI + DA - IAA + OP } \mp \text { I + Firm, }
$$

where the dependent variable is the natural logarithm of audit fee and the explanatory variables are:

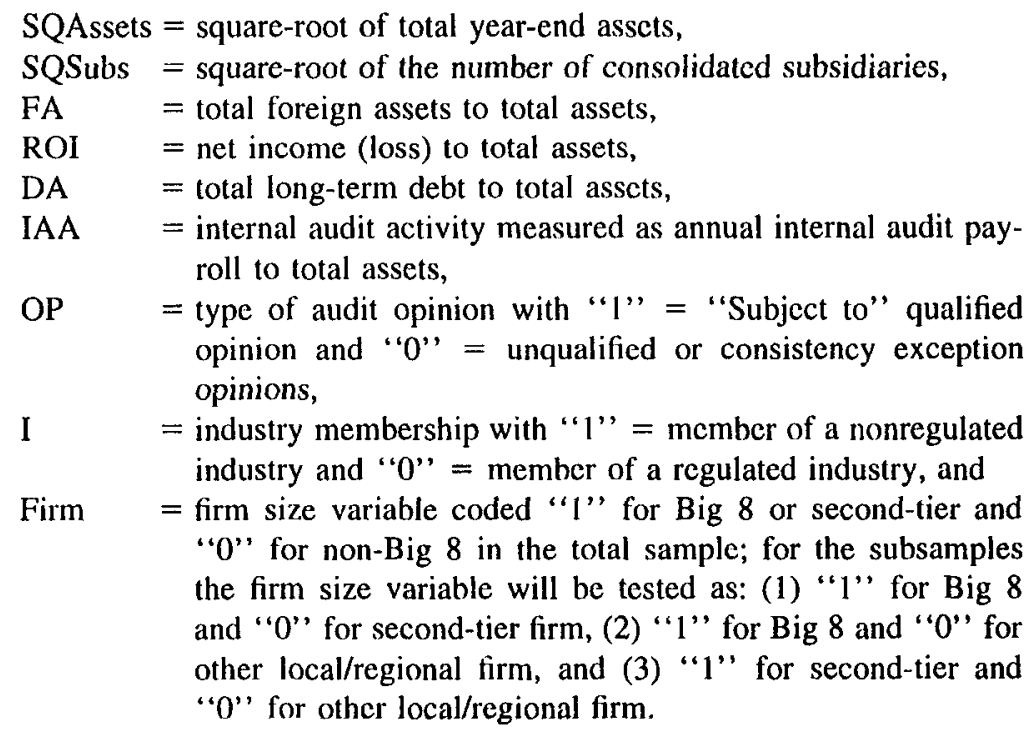

The models are run and the results are compared to that of Francis and Simon.

\section{Results}

Descriptive statistics are reported in Table 1 for variables in the multiple regression fec model. Mean assets are $\$ 43.4$ million, which is somewhat larger than Francis and Simon [1] with average assets of $\$ 30$ million and very close to Palmrose [2] with average assets of $\$ 40$ million. The mean assets for each of these studies are considerably smaller than that of Simunic [3], who had average assets of $\$ 177$ million.

The Big 8 audited 38 percent of the sample. The mean assets audited by the 
TABLE 1

Descriptive Statistics

\begin{tabular}{|c|c|c|c|}
\hline & & & \\
\hline & Big 8 & Non-Big 8 & Total \\
\hline Number of Observations & 53 & 86 & 139 \\
\hline Fee & $\begin{array}{c}74.06 \mathrm{t} \\
(54.55 \mathrm{t})\end{array}$ & $\begin{array}{c}39.29 t \\
(36.85 \mathrm{t})\end{array}$ & $\begin{array}{c}52.55 \mathrm{t} \\
(47.38 \mathrm{t})\end{array}$ \\
\hline Assets & $\begin{array}{c}60,970.36 t \\
(42,795.55 t)\end{array}$ & $\begin{array}{c}32,578.27 t \\
(41,125.79 t)\end{array}$ & $\begin{array}{c}43,404.03 t \\
(43,856.85 t)\end{array}$ \\
\hline Subs & $\begin{array}{c}3.96 \\
(4.61)\end{array}$ & $\begin{array}{c}1.94 \\
(1.89)\end{array}$ & $\begin{array}{c}2.71 \\
(3.34)\end{array}$ \\
\hline FA & $\begin{array}{c}1.34 \\
(5.64)\end{array}$ & $\begin{array}{l}.12 \\
(.76)\end{array}$ & $\begin{array}{c}.58 \\
(3.56)\end{array}$ \\
\hline $\mathrm{ROI}^{\mathrm{n}}$ & $\begin{array}{c}.03 \\
(.08)\end{array}$ & $\begin{array}{l}-.03 \\
(.21)\end{array}$ & $\begin{array}{l}-.01 \\
(.18)\end{array}$ \\
\hline DA & $\begin{array}{l}.23 \\
(.20)\end{array}$ & $\begin{array}{l}.18 \\
(.20)\end{array}$ & $\begin{array}{l}.20 \\
(.20)\end{array}$ \\
\hline IAA & $\begin{array}{c}.02 \\
(.07)\end{array}$ & $\begin{array}{c}.00 \\
(.00)\end{array}$ & $\begin{array}{c}.01 \\
(.04)\end{array}$ \\
\hline$\%$ of observations with "subject to" opinion & $1.9 \%$ & $10.5 \%$ & $7.2 \%$ \\
\hline$\%$ of observations in Regulated industries ${ }^{\mathbf{b}}$ & $30.2 \%$ & $33.7 \%$ & $32.4 \%$ \\
\hline$\%$ of Second-tier firms & & $58.1 \%$ & \\
\hline Mean (Standard deviation) & & & \\
\hline
\end{tabular}

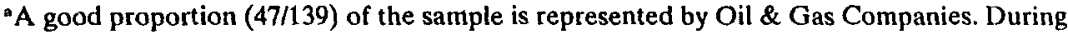
the period of this study (1983-1985) many Oil \& Gas Companies reported losses due to the slump in the industry. This explains, at least in part, why the averages are low.

${ }^{b}$ Industries classified as regulated in the sample are Trucking, Telecommunication, Gas \& Electric Utilities, Savings \& Loan, and Insurance. These industries have been traditionally classificd as regulated, though Trucking and Telecommunication have been deregulated by the $1980 \mathrm{~s}$ to a substantive degree.

Fee-Annual external audit fee.

Assets-Total year end assets.

Subs-Number of consolidated subsidiaries.

FA-Foreign assets to total assets.

ROI-Net income (loss) to total assets.

DA-Long-term debt to total assets.

IAA - Internal audit activity measured as annual internal audit payroll to total assets.

Big 8 and non-Big 8 are $\$ 61$ million and $\$ 33$ million, respectively. The mean number of consolidated subsidiaries of companies audited by Big 8 and non-Big 8 are 3.96 and 1.94, respectively. Companies audited by the Big 8 firms appear to be larger and more complex than the companies audited by non-Big 8 firms. The related mean audit fees for Big 8 and non-Big 8 firms are $\$ 74$ thousand and $\$ 39$ thousand, respectively. The regression equation does control for the cross-sectional differences in auditee characteristics. 
The ordinary least-squares estimates for each of the fivc regressions are reported in Table 2. Good linear fits are achieved in the five regressions. Values of adjusted $R^{2}$ range from .73 to .80 . Tests such as Kolmogorov $D$ statistic for normally distributed residuals and Goldfeld-Quandt [12] for constant variance did not indicatc any violations of the assumptions of the regression model. ${ }^{6}$ Further, the correlation matrix suggests no collinearity problems among the independent variables. The higher correlation (.59) among the firm size variables is expected since both Big 8 and second-tier are coded " 0 " for other local/regional firms.

According to the regression models in Table 2, SQAssets was positive and significant in all the models at $\alpha=.01$, and SQSubs was positive and significant in all of the models at $\alpha=.10$ or less. FA was positive and significant in four of the five models at $\alpha=.10$ or less. A variable, DA, measuring the amount of longterm debt in the capital structure was positive and significant in three models at $\alpha$ $=.10$ or less. Also a "crude" industry variable, I, measuring regulated/nonregulated industry membership was positive and significant in four of the five models at $\alpha=.05$ or less. All of these control variables were in the direction expected. No direction was hypothesized for I. Other control variables were not significant, but were included to minimize the chance for model misspecification. It is interesting to note that when SQAsscts is included as the only independent variable, it explains 70 percent of the variation in audit fees. When SQSubs and FA are added the adjusted $R^{2}$ increases to 71 percent. Thus, auditee size and complexity appear to explain most of the variation in audit fees.

The regression estimate for the Big 8 firm size test variable indicates the existence of a $\mathrm{Big} 8$ price premium. In the test of the Big 8 versus all non-Big 8 auditors, the Big 8 coefficient is positive and significant at $\alpha=.05$. This result is consistent with Francis and Simon [1] and Palmrose [2], but inconsistent with Simunic [3] who did not find a price difference. As explained previously, this difference in findings may be attributable to the fact that the companies in Simunic's sample are considerably larger than the companies of the other samples.

The subsample analyses indicate that the Big 8 premium exists only with respect to other local/regional firms. In the test of the Big 8 versus second-tier auditors, the Big 8 coefficient is not significant at conventional levels. Perhaps the second-tier firm brand name is just as valuable as the Big 8 brand name in the small-auditee market segment. In the test of the Big 8 versus local/regional firms, the Big 8 coefficient is positive and significant at $\alpha=.01$. These results are somc-

6. A null hypothesis that the residuals are normally distributed cannot be rejected at the .05 level for the sample using the Kolmogorov Smirnov test contained in the SAS program. The Goldfeld-Quandt test is used to test for violation of the constant variance assumption. The null hypothesis of homoscedasticity cannot be rejected at the .05 level for the model. In the Goldfeld-Quandt test, regression models are run on an upper and lower proportion of sample observations. A central number of observations are omitted. The null hypothesis is that the sum of squared errors for the upper and lower percentages of the sample are equal. The central 20 percent of the observations were dropped for this test. 


\section{TABLE 2}

\section{Regression Estimates}

\section{Coefficients (1-statistics)}

\begin{tabular}{|c|c|c|c|c|c|}
\hline Variable & $\begin{array}{c}\text { Big } 8 \text { vs } \\
\text { Non-Big } 8 \\
\text { (full sample) }\end{array}$ & $\begin{array}{c}\text { Big 8 vs } \\
\text { Second-tier } \\
\text { (subsample) }\end{array}$ & $\begin{array}{c}\text { Big } 8 \text { vs } \\
\text { Local/Regional } \\
\text { (subsample) }\end{array}$ & $\begin{array}{l}\text { Second-tier vs } \\
\text { LocaURegional } \\
\text { (subsample) }\end{array}$ & $\begin{array}{c}\text { Big } 8 \text { vs } \\
\text { Second-Tier v } \\
\text { LocalRegiono } \\
\text { (full sample) }\end{array}$ \\
\hline Intercept & $\begin{array}{c}1.75 \\
(9.13)^{*}\end{array}$ & $\begin{array}{c}2.40 \\
(13.79)^{*}\end{array}$ & $\begin{array}{c}1.57 \\
(6.64)^{*}\end{array}$ & $\begin{array}{c}1.40 \\
(6.13)^{*}\end{array}$ & $\begin{array}{c}1.57 \\
(9.25)^{*}\end{array}$ \\
\hline SQAssets & $\begin{array}{c}.01 \\
(13.92)^{*}\end{array}$ & $\begin{array}{c}.01 \\
(13.46)^{*}\end{array}$ & $\begin{array}{c}.01 \\
(6.96)^{*}\end{array}$ & $\begin{array}{c}.01 \\
(9.56)^{*}\end{array}$ & $\begin{array}{c}.01 \\
(12.54)^{*}\end{array}$ \\
\hline SQSubs & $\begin{array}{c}.08 \\
(2.81)^{*}\end{array}$ & $\begin{array}{c}.02 \\
(1.61)^{* * *}\end{array}$ & $\begin{array}{c}.02 \\
(2.18)^{* * *}\end{array}$ & $\begin{array}{c}.09 \\
(3.97)^{*}\end{array}$ & $\begin{array}{c}.03 \\
(1.57)^{* * *}\end{array}$ \\
\hline FA & $\begin{array}{c}.01 \\
(.81)\end{array}$ & $\begin{array}{c}.02 \\
(1.96)^{* *}\end{array}$ & $\begin{array}{c}.02 \\
(1.34)^{* * *}\end{array}$ & $\begin{array}{c}.12 \\
(1.80)^{* *}\end{array}$ & $\begin{array}{c}.02 \\
(1.63)^{* *}\end{array}$ \\
\hline ROI & $\begin{array}{c}-.11 \\
(-.42)\end{array}$ & $\begin{array}{c}.02 \\
(.07)\end{array}$ & $\begin{array}{c}-.18 \\
(-.56)\end{array}$ & $\begin{array}{c}.17 \\
(.63)\end{array}$ & $\begin{array}{c}.06 \\
(.26)\end{array}$ \\
\hline DA & $\begin{array}{c}.22 \\
(.96)\end{array}$ & $\begin{array}{c}.58 \\
(2.25)^{* *}\end{array}$ & $\begin{array}{r}.29 \\
1.14\end{array}$ & $\begin{array}{c}.35 \\
(1.33)^{* * *}\end{array}$ & $\begin{array}{c}.41 \\
(2.00)^{* *}\end{array}$ \\
\hline IAA & $\begin{array}{c}-.38 \\
(-.32)\end{array}$ & $\begin{array}{c}-.27 \\
(-.29)\end{array}$ & $\begin{array}{c}.38 \\
(.34)\end{array}$ & $\begin{array}{c}.53 \\
(.41)\end{array}$ & $\begin{array}{c}.36 \\
(.30)\end{array}$ \\
\hline OP & $\begin{array}{c}.09 \\
(.50)\end{array}$ & $\begin{array}{c}.09 \\
(.56)\end{array}$ & $\begin{array}{c}.24 \\
(.71)\end{array}$ & $\begin{array}{c}-.09 \\
(-.53)\end{array}$ & $\begin{array}{l}-.02 \\
(-.14)\end{array}$ \\
\hline I & $\begin{array}{c}.21 \\
(2.16)^{* *}\end{array}$ & $\begin{array}{c}.05 \\
(.61)\end{array}$ & $\begin{array}{c}.24 \\
(1.94)^{* *}\end{array}$ & $\begin{array}{c}.28 \\
(2.45)^{*}\end{array}$ & $\begin{array}{c}.21 \\
(2.42)^{*}\end{array}$ \\
\hline Firm-Big 8 & $\begin{array}{c}.18 \\
(1.91)^{* *}\end{array}$ & $\begin{array}{l}-.04 \\
-.43\end{array}$ & $\begin{array}{c}.72 \\
(5.51)^{*}\end{array}$ & & $\begin{array}{c}.65 \\
(5.89)^{*}\end{array}$ \\
\hline Firm-Second-tier & & & & $\begin{array}{c}.66 \\
(5.15)^{*}\end{array}$ & $\begin{array}{c}.69 \\
(6.51)^{*}\end{array}$ \\
\hline Sample & $\mathbf{n}=139$ & $\mathrm{n}=103$ & $n=89$ & $\mathrm{n}=86$ & $n=139$ \\
\hline Adjusted $R^{2}$ & $\begin{array}{c}.73 \\
41.74 *\end{array}$ & $\begin{array}{c}.75 \\
34.65 *\end{array}$ & .80 & .77 & .79 \\
\hline F-ratio & $41.74^{*}$ & $34.65^{*}$ & $40.16^{*}$ & $32.23^{*}$ & $53.83^{*}$ \\
\hline
\end{tabular}

Significance levels (one-tail tests): ${ }^{*}=.01,{ }^{* *}=.05,{ }^{* * *}=.10$.

SQAssets-Square-root of total assets.

SQSubs-Square-root of the number of consolidated subsidiaries.

FA-Foreign assets to total assets.

ROI-Net income (loss) to total assets.

DA-Long-term debt to total assets.

IAA-Internal audit activity measured as annual internal audit payroll to total assets.

OP-Type of audit opinion with " 1 " = "subject to" qualified opinion and " 0 " = unqualified or consistency exception opinions.

I-Industry membership with " 1 " = member of a nonregulated industry and " 0 " = member of a regulated industry.

Firm-Big 8-Big 8 firm indicator with " 1 " = Big 8 firm and " 0 " = other.

Firm-Second-tier-Second-tier indicator with " 1 " = Second-tier firm and " 0 " = other. 
what different from Francis and Simon's in that they found a Big 8 price premium to exist with respect to both second-tier and local/regional firms. The difference in results between this study and Francis and Simon could be attributable to a number of factors. For instance, the average assets of this study are $\$ 13.4$ million greater than that of Francis and Simon. Further, even though the response rates were comparable, the Francis and Simon.sample was considerably larger with 208 observations. Given that the present study is based on a considerably smaller sample the results are, all other things being equal, less generalizable than theirs. The present study, however, did cover the same time period as Francis and Simon.

Sevcral variables were included in this study that were not considered by Francis and Simon; those variables include the internal audit activity variable (IAA) and the regulated/nonregulated industry indicator variable (I). Nevertheless, these two variables do not appear to account for the difference in these studies. When the data is run without IAA and I the basic results are unchanged. ${ }^{7}$ The IAA variable was not significant in this study, but it was tested and controlled. There is no indication that Francis and Simon considered the effect of the existence of internal auditors. Further, the industry indicator variable was positive and significant at $\alpha=.05$ or better for four of the five models. The industry variable is not significant for the model of Big 8 versus second-tier firms, which is one of the models that differs between the studies. Francis and Simon did not control for industry effects (not even crudely as done here), but did indicate that their sample was well dispersed across industries. The results of the industry variable are consistent with Palmrose [2] and Simunic [3] that audit fees tend to be higher in nonregulated industrics compared to regulated.

The present study also provided evidence of a second-tier price premium over local/regional firms. The second-tier firm size variable was positive and significant at $\alpha=.01$. Francis and Simon found no difference in audit pricing between secondtier and local/regional firms in their sample. Factors that could account for the difference in results were already discussed. Since only two studies (considering the present one) to date have examined three audit firm size classes in the small auditee segment of the U.S. market and those studies are not totally consistent, the need for further research is apparent. The use of the three size classes does provide a richer test of the association between auditor size and audit fees.

Finally, the regression on the full sample using two auditor variables (Big 8 and second-tier) is consistent with the subsample results. The Big 8 coefficient is significant, indicating a price premium over local/regional firms, and the secondtier coefficient is significant, indicating a price premium over local/regional firms.

7. The findings of the present study with respect to the auditor size variable are unchanged when IAA and I are dropped. However, it is not known whether the results of the study by Francis and Simon would remain substantially unchanged with the inclusion of these variables in their models. Thus, one cannot be totally certain that these two variables do not account for the difference in the two studies. 


\section{Further Tests for Model Misspecification}

Since Table 1 shows that there may be systematic differences between clients audited by the Big 8 versus the non-Big 8 , further analysis is necessary to determine whether these underlying differences in the two sets of companies are driving the empirical results on the auditor variables. If the regression model used in this study is misspecified, then it is possible for cross-sectional differences among the independent variables to confound the auditor size variable. As auditee size increases there is a greater likelihood of having a Big 8 auditor, and it is therefore possible that the auditor size variable is really picking up a residual auditee size effect.

Although the regression equation controls for cross-sectional differences in auditee characteristics, the tests discussed in this section provide additional assurance that these differences are not driving the results. For instance, if auditee size is a confounding variable, an alternative specification of the model would be to deflate audit fee by auditee size [1,3] rather than including it as an independent variable. When this alternative model was estimated the results were similar.

A second test was performed by adding interaction terms to the model for the Big 8 dummy variable with each of the other independent variablcs. The interaction terms deal with the possibility that the auditor dummy variable captures not only intercept differences between regressions for different auditor classes, but also slope effects due to a confounding of auditor size and other independent variables. With the interaction terms in the model, the Big 8 variable remained positive and significant at $\alpha=.01$. The only interaction terms that were significant were SQSubs, FA, and ROI, all of which had positive coefficients.

The additional tests discussed in this section support the basic results reported in Table 2. It does not appcar that underlying differences between clients audited by the Big 8 versus the non-Big 8 are driving the results on the auditor variables.

\section{Conclusion}

The main purpose of this study was to provide further evidence with respect to audit pricing by second-ticr firms compared to Big 8 and local/regional firms in the small-client segment of the U.S. audit market. The evidence from this sample strongly supports the existence of a Big 8 price premium, which is consistent with Francis and Simon and Palmrose. This is the second study to use three classes of audit firm size. Francis and Simon were the first to use three classes of audit firm size and provided evidence that the Big 8 price premium exists with respect to both second-tier and local/regional firms. The present study provides evidence that the Big 8 price premium exists only with respect to local/regional firms. Perhaps the second-tier firm brand name is just as valuable as the Big 8 brand name in this market segment, that is, smaller publicly listed companies. Further, the present study provides evidence of a second-tier price premium over local/regional firms. Differences in auditee size, sample size, and model specification may explain the difference in results for the two studies. 
Given the assumption of competition in the small auditee market segment, higher Big 8 prices imply Big 8 product differentiation. This study is not only consistent with Francis and Simon and Palmrose in the U.S. market, but also with studies of the Australian market [4,5]. The second-tier price premium would also imply product differentiation, given the assumed competitiveness of the smallauditee market segment.

\section{REFERENCES}

1. J. Francis and D. Simon. "A Test of Audit Pricing in the Small-Client Segment of the U.S. Audit Market." The Accounting Review 62, no. 1 (1987): 145-157.

2. Z. Palmrose. "Audit Fees and Auditor Size: Further Evidence." Journal of Accounting Research 24, no. 1 (Spring 1986): 97-110.

3. D. Simunic. "The Pricing of Audit Services: Theory and Evidence." Journal of Accounting Research 18, no. 1 (Spring 1980): 161-190.

4. J. Francis and D. Stokes. "Audit Prices, Product Differentiation and Scale Economies: Further Evidence from the Australian Market." Journal of Accounting Research 24, no. 2 (Autumn 1986): $383-393$.

5. J. Francis. "The Effect of Audit Firm Size on Audit Prices: A Study of the Australian Market." Journal of Accounting and Economics 6, no. 2 (March 1984): 133-151.

6. Standard and Poor's Register of Corporations, Directors, and Executives. Vols. 1 and 3. New York: Standard and Poor's Corporation. 1983-1985.

7. S. Harris. Who Audits America. Menlo Park, Calif.: Data Financial Press, 1983-1985.

8. W. Wallace. "Internal Auditors Can Cut Outside CPA Costs." Harvard Business Review 62 (March/April 1984): 16, 20.

9. P. Danos and J. Eichenseher. "Audit Industry Dynamics: Factors Affecting Changes in ClientIndustry Market Shares." Journal of Accounting Research 20 (Autumn 1982): 604-616.

10. P. Danos and J. Eichenseher. "Long-Term Trends Toward Seller Concentration in the U.S. Audit Market." The Accotming Review 61 (October 1986): 633-650.

11. J. Eichenseher and P. Danos. "The Analysis of Industry Specific Auditor Concentration: Towards an Explanatory Model." The Accounting Review 56 (July 1981): 479-492.

12. S. Goldfeld and R. Quandt. "Some Tests for Homoscedasticity." Journal of the American Statistical Association (June 1965): 539-547.

13. M. Stevens. The Accounting Wars. New York: Macmillan, 1985. 